\title{
AN OUTLINE OF AN ASYMMETRIC TWO-COMPONENT THEORY OF ASPECT*
}

\author{
BOGLÁRKA NÉMETH \\ Babeş-Bolyai University \\ Mihail Kogalniceanu nr. 1 \\ RO-400084 Cluj-Napoca \\ Romania \\ b_nemeth@bcucluj.ro
}

\begin{abstract}
The paper presents the bases of an asymmetric two-component model of aspect. The main theoretical conclusion of the study is that (grammatical) viewpoint aspect and situation aspect are not independent aspectual levels, since the former often modifies the input situation aspect of the phrase/sentence. As it is shown, besides the arguments and adjuncts of the predicate, viewpoint aspect is also an important factor in compositionally marking situation aspect. The aspectual framework put forward in the paper is verified and illustrated on the basis of the aspectual system of Hungarian and some examples taken from English linguistic data.
\end{abstract}

Keywords: compositionality, viewpoint aspect, situation aspect, progressivity, habituality, existential quantification, perfect-like constructions

This paper is concerned with some basic theoretical problems related to aspectuality, especially with the possibility of elaborating an adequate two-component model of aspect, and with the necessary modifications regarding previous general models. I accept the basic distinction formulated by Smith (1991), according to which the two elementary components of aspectuality are situation aspect and viewpoint aspect, adding the stipulation that there is a hierarchical relation between the two components:

* I would like to thank Ferenc Kiefer and the anonymous reviewers for their insightful comments on previous versions of this paper. All remaining errors are, of course, solely my own. 
the basic universal component seems to be situation aspect, while viewpoint aspect is an additional component which is language specific (i.e., it is not a universal phenomenon) and has an important role in the compositional encoding of situation aspect. It will be demonstrated that the two components are not independent systems.

Situation aspect will be defined as a category compositionally encoded at sentence level, and determined by the aspectual features assigned to the event structure of a predicate, the main aspectual features being $[ \pm$ Telic $]$ and $[ \pm$ Dynamic], the valid combinations of which result in the three basic categories of situation aspect: events [+Telic, +Dynamic], processes [-Telic, +Dynamic] and states [-Telic, -Dynamic] (cf. Dowty 1986; Smith 1991; Boland 2006; etc.).

Viewpoint aspect will be considered to be a different component of the complex aspectual system. The categories that belong to this level are usually marked by grammatical means and are not inherent parts of the semantics of the predicate. Their function is focusing on a specific part or on the quantificational features of the event structure assigned to a predicate. As Smith (1991) and Boland (2006) point out, only the focused part(s) are available for the semantic interpretation. The categories labelled here as viewpoint categories are the perfective, the imperfective, the ingressive, the progressive, the egressive and the perfect, and they are formally defined by means of the well-known Reichenbachian tense system (speech time, event time and reference time).

The relation of the two aspectual levels, i.e., situation aspect and viewpoint aspect, will be illustrated by the Hungarian aspectual system, by describing the viewpoint aspect categories that can be found in Hungarian and by analysing their role in marking situation aspect. The viewpoint categories present in Hungarian are the following: the progressive, the existential, the habitual, the stative resultative and the eventive resultative. I will claim that, according to the relevant tests, the progressive and the habitual result in complex process predicates in Hungarian, i.e., these categories have a detelicising function; the stative resultative construction results in complex stative predicates, i.e., the category changes the [+Telic, + Dynamic] feature values of the input predicate to [-Telic, -Dynamic]; finally, the eventive resultative and the existential result in complex event predicates (the latter has a telicising function, while the former leaves the input situation aspect unchanged due to the telicity requirement that holds for the input predicate of the construction type). 
The structure of the paper is as follows: section $\mathbf{1}$ briefly discusses some theoretical questions related to aspectuality in general, including the outline of a general aspectual framework based on linguistic data and on the conclusions of the most influential aspect theories; section $\mathbf{2}$ serves as an application of the theoretical framework to the Hungarian aspectual system: it presents the Hungarian viewpoint categories and briefly describes them in the perspective of viewpoint and situation aspect; finally, section 3 summarises the main conclusions of the paper.

\section{The aspectual framework}

The applicability of universal aspect theories to the description of Hungarian and other aspectually similar languages is an important issue both in Hungarian and in general aspectology (Hungarian being theoretically relevant by showing a lot of specific properties of aspectuality). A comparative analysis of the various aspect models presented by the most important theoretical approaches leads to the conclusion that there are some phenomena of aspectuality that are especially hard to explain adequately. Some of these are: the exact nature of aspectual compositionality, the role of viewpoint aspect in marking semantic aspectual categories, and the relation between the diverse aspectual categories.

The analysis of these problems leads to an alternative general approach based on universal principles, also applicable to such aspectually complex languages as Hungarian. The present section gives an outline of a two-component aspect model primarily based on Smith (1991) and modified according to the reinterpretation of some crucial concepts related to aspectuality, like the relation of viewpoint aspect and situation aspect, and the categories belonging to the level of viewpoint aspect.

\subsection{The levels of aspectuality and their categories}

This section presents the fundamental principles of a modified twocomponent aspectual model based on a comparative study of the most influential theories of aspectuality and the linguistic data presented in these works. The specific problems related to the works in question will not be presented here in detail; I only aim to emphasise the conclu- 
sions that are relevant to the discussion on aspectual categories and the presentation of a general model. ${ }^{1}$

According to Smith (1991), the two elementary components of aspectuality are situation aspect and viewpoint aspect. Based on the linguistic evidence presented by Smith (1991) and others (e.g., Binnick 1991; Bertinetto-Delfitto 2000; de Swart 2000; Borik 2002; Michaelis 2002; Borik-Reinhart 2004; Boland 2006), this assumption seems to be tenable, on the stipulations that situation aspect is a universal category, while viewpoint aspect is a language specific phenomenon (i.e., there are many languages that lack grammatical viewpoint aspect categories, cf. Dahl 1985; Kiefer 1996), and that there is a hierarchical relation between the two components.

The forthcoming subsections present the basic categories of situation aspect (see 1.1.1), i.e., states, processes and events, while the following categories will be considered as the most frequent viewpoint aspects: the perfective vs. imperfective aspect, the categories of phasal aspect (the progressive, the ingressive, the egressive) and the categories of perspectival (the prospective, the perfect) and quantificational aspect (the existential, the iterative, the habitual, etc.). (For the justification of this categorisation and the various other approaches concerning these categories, see Boland 2006, 35-65; Comrie 1976; Dahl 1985; Smith 1991; Binnick 1991, etc., and subsection 1.1.2 of the present paper.)

As far as the relation of the two aspectual components and the compositionality of aspect are concerned, the two levels are not independent coordinate systems, because - according to the relevant linguistic tests - viewpoint aspect can change the (lexically or compositionally encoded) situation aspect of the phrase. Consequently, somewhat similarly to Michaelis (2002) and de Swart (2000), ${ }^{2}$ I consider viewpoint aspect to be an important subsystem in the compositional marking of aspect, thus I assume a hierarchical relation between the two levels: the basic aspectual segment is the universally present component of situation aspect, while viewpoint aspect is an additional component that is not present in the aspectual system of each language (see section 1.2).

${ }^{1}$ For a detailed analysis of the aspectual theories in question, see Németh (2010).

2 De Swart's approach is summarised as follows: "I assume that grammatical aspect applies to eventuality descriptions to provide a perspective on the situation [...] Aspectual operators are interpreted as eventuality modifiers, so they map sets of eventualities (of a certain type) onto sets of eventualities (of some possibly other type)" (2000, 3). 


\subsubsection{Situation aspect}

Situation aspect is an aspectual component that, in terms of Verkuyl (1972; 2005), is compositionally marked in the sentence. The function generally assigned to situation aspect is that of linguistically encoding the event structure of the eventuality expressed by predicates/phrases. The schematic conceptualisation of this event structure encoding is generally modeled by means of some conventionally determined aspectual features. According to the general literature on aspect and event structure, the three elementary categories can be distinguished based on the features $[ \pm$ Dynamic $]$ and $[ \pm$ Telic $]$. Smith's third feature $[ \pm$ Durative $]$ has secondary importance from the point of view of distinguishing events, processes and states; therefore, it is excluded here from the set of basic features and distinguishing criteria. ${ }^{3}$

Based on the above, we generally distinguish [-Dynamic] eventualities, i.e., states, from [+Dynamic] eventualities, and further classify the latter into $[-$ Telic $]$ eventualities, i.e., processes, and $[+$ Telic $]$ ones, i.e., events (see (1)).

\begin{tabular}{lcc}
\hline Situation aspect & Dynamic & Telic \\
\hline State & - & - \\
Process & + & - \\
Event & + & + \\
\hline
\end{tabular}

The most frequently used telicity tests are the linguistic test of adverbial modification (see (2a,c) below) and the distributivity test based on the so-called subinterval criterion (for Borik-Reinhart 2004's adaptation of the distributivity test, see $(2 \mathrm{~b}, \mathrm{~d}))^{4}{ }^{4}$

(2) (a) Peter wrote *in an hour/for an hour.

(b) $e$ is atelic if $A T(e, I) \rightarrow \exists I^{\prime}\left(I^{\prime} \neq I\right) \& A T\left(e, I^{\prime}\right)$

(c) Peter wrote a letter in an hour $/ *$ for an hour.

(d) $e$ is telic if $A T(e, I) \rightarrow \exists \neg I^{\prime}\left(I^{\prime} \neq I\right) \& A T\left(e, I^{\prime}\right)$

3 This does not mean, of course, that the distinction between accomplishments $([+$ Durative $])$ and achievements $([-$ Durative $])$ is irrelevant to the discussion of any aspectual phenomena (cf. Smith 1991).

${ }^{4} e=$ eventuality variable, $I=$ temporal interval variable, $A T=$ the relation of coincidence. 
According to the adverbial modification tests, atelic predicates, like that in sentence (2a) above, only combine with adverbials of the type for an hour (two weeks/three years, etc.), and not with the type in an hour (two weeks/three years, etc.), while telic predicates, like the one in (2c), combine with adverbials of the type in an hour (two weeks/three years, etc.), and they are usually incompatible with adverbials of the type for an hour (two weeks/three years, etc.). The corresponding distributivity tests of interval semantics, illustrated in (2b) and (2d) above, aim at detecting the interval features assigned to the predicate in question: an eventuality is telic if there is no subinterval of the eventuality time for which the occurrence of the same eventuality would hold (see (2b)), while the eventuality is atelic if there is such a subinterval.

According to Michaelis (2002) and others, the feature of distributivity can be further classified into weak and strong distributivity: strong distributivity means that any subinterval of the eventuality time assigned to the eventuality can be characterised by the same eventuality, while weak distributivity means that there is at least one subinterval for which the occurrence of the same eventuality holds, but this does not apply to each subinterval in question. Within the confines of interval semantics, the purpose of this distinction is to isolate states from processes: predicates that show the feature of weak distributivity are processes, while predicates that show the feature of strong distributivity are states.

The most frequently used linguistic tests of dynamicity are based on compatibility with progressive viewpoint aspect or any other category - available in the language in question - that implies a process interpretation, e.g. compatibility with the question What are you doing now? and the like.

(3) (a) What are you doing now?

(b) I am running/writing/working.

(c) *I am knowing/loving [something].

(Vendler 1967, 99)

Expressions like these do not combine with stative predicates (in their basic meaning), while their combinations with process predicates result in linguistically and pragmatically well-formed sentences (see ( $3 \mathrm{a}-\mathrm{c})$ above).

\subsubsection{Viewpoint aspect}

Viewpoint aspect belongs to a level different from that of situation aspect. Its categories are not encoded in the semantics of the verb/phrase 
by means of inherent aspectual features, but they are generally marked by some grammatical category (morphological item, periphrastic expression), ${ }^{5}$ their function being to focus on a certain part or on the quantificational features of the event structure assigned to a predicate. ${ }^{6}$ As Smith (1991) and Boland (2006) point out, only the focused part of the event structure is available to the semantic interpretation.

In describing the level of viewpoint aspect, I keep Smith's term, but I classify its different subdomains taking into account the observations presented in Comrie (1976), Dahl (1985) and Boland (2006) among others, while the categories are determined by means of the Reichenbachian temporal model (cf. Reichenbach 1947), in a way similar to the method used by Klein (1994) and Borik-Reinhart (2004). ${ }^{7}$

As has already been mentioned, I take into account (as basic viewpoint aspect categories) Comrie's perfective-imperfective opposition pair,

${ }^{5}$ Hence the often used term for this level of aspect: grammatical aspect.

${ }^{6}$ We must not forget that the choice of situation aspect categories works in some degree similarly to the use of viewpoint categories. The same situation (in reality), for example that of running, can have many different linguistic representations: it can be represented as a process (Péter hosszasan futott 'Peter was running for a long time'), as an event (Péter befutott az épületbe 'Peter ran into the building') or even as a state (Péter (nagy) futásban volt ' $\approx$ Peter was in the state of running (fast)'). About the questions related to the speakers' choice of aspectual category see Smith (1986).

The results of the experiments presented in van Stutterheim et al. (2009) serve supplementary data regarding this question. The study is based on the following experiment: English, German and Dutch speakers were provided with non-verbal, visual information (video recordings) about real eventualities and asked to express linguistically the eventualities perceived. The authors came to the conclusion that the task had been accomplished the fastest by speakers of languages that have a grammaticalised progressive, while speakers of languages lacking these forms had accomplished the same task a lot more slowly than the others, because the identification of an event takes more time than the identification of its process subeventuality using the progressive viewpoint (cf. op.cit., 205-14).

${ }^{7}$ We must note here that telic and atelic predicates can also be described using the categories of this temporal model: the RT of sentences with telic predicates includes the whole ET, while that of sentences with atelic predicates does not include the initial and final points of the ET. Regarding the feature [ \pm Dynamic], the system cannot be used for determining the event schemes of the different (dynamic vs. stative) predicates. This constitutes an argument against the essential difference of the telic-atelic opposition - at the level of situation aspect - and the viewpoint opposition perfective-imperfective. Section $\mathbf{1 . 2}$ below briefly touches upon this question. 
the categories of phasal aspect (the progressive, the ingressive, the egressive $)^{8}$ and the categories of perspectival (the prospective, the perfect) and quantificational aspect (the existential, the iterative, the habitual) (cf. Comrie 1976; Dahl 1985; Boland 2006). ${ }^{9}$ The first three subcategories are exemplified in (4) below.

(4) (a) I was going to wash the dishes.

(b) At 12.30, I started washing the dishes.

(c) At 12.35, I was washing the dishes.

(d) At 12.55, I finished washing the dishes.

(e) At 12.56, I had washed the dishes.

(f) At 12.56, the dishes were washed.

(g) From 12.30 to 12.55 , I washed the dishes.

These sentences contain predicates of different viewpoint categories that focus on different parts of the event structure, i.e., the relation of RT and ET is realised differently in the above cases: in the case of the prospective aspect RT precedes ET (see (4a)); ingressive aspect focuses on the starting point of the ET (i.e., RT contains the starting point of the ET, see (4b)); the imperfective/progressive places the RT inside the interval of ET (i.e., RT does not contain the starting and final points of the ET, see (4c)); the RT of egressive predicates focus on the final point of the ET (see (4d)); the RT of the perfect and the resultative succeeds the ET (i.e., the category focuses on the time interval that follows the ET assigned to the predicate, see $(4 \mathrm{e}-\mathrm{f})$ ); while the perfective focuses on the eventuality expressed by the predicate as a whole (i.e., RT contains ET including its starting and final points, see $(4 \mathrm{~g}))$.

The categories belonging to the subcomponent of quantificational aspect (the existential, the iterative and the habitual aspect) have a similar function (see $(5 \mathrm{a}-\mathrm{c})$ below).

8 The categories of phasal aspect - with the exception of the progressive - are classified by Smith (1991) as categories of shifted situation aspect while, in the case of languages that mark these categories morphologically, the Slavic and Hungarian literature talks about the derivation of morphological Aktionsart by means of Aktionsart-prefixes and suffixes (cf. Kiefer 2006, 137-204).

9 The categories enumerated are not necessarily present in a grammaticalised form in the aspectual system of each language. 
(5) (a) I have lived in London (before/in the last two years).

(b) Peter was coughing for an hour.

(c) We used to run miles.

Existential aspect, illustrated in (5a), leaves the exact ET unspecified: ET is placed somewhere inside the RT, but there is no exact time interval assigned to it. RT can be specified by means of time adverbials and in the lack of these adverbials it is interpreted as the time interval ending with ST. Existential aspect expresses that the eventuality expressed by the input predicate occurred at least once during the interval of RT.

As far as iterativity and habituality are concerned, both categories express the multiple occurrence of the eventuality expressed by the input predicate, these occurrences being conceptualised in a way similar to the successive subphases of process predicates. In these cases - similarly to the imperfective/progressive-ET contains RT, but the ET' assigned to the phases of the eventuality in question remain unspecified.

These categories are marked in various ways in the different languages, for example by aspectual verbs, morphology, periphrastic phrases, or syntactic structures. The description of these categories and the discussion of the specific syntactic phenomena related to them is the task of studies about the aspectual system of the individual languages.

It is important to emphasise that this aspectual level is itself segmented, i.e., it has different subcomponents, the term viewpoint aspect being used here as a collective term for those categories that have the function of grammatically encoding the speaker's perspective. ${ }^{10}$ The different nature of these components is shown by the fact that they can operate on one another. As the sentences in $(6 a-c)$ illustrate, these aspectual categories can modify input predicates/phrases that already have some kind of aspectual specification, i.e., their viewpoint category is marked.

(6) (a) John has been listening to music.

(b) When I visited him, he used to be playing in the garden.

(c) I was starting to drink my beer when he entered.

10 The known aspect definitions do not exclude this interpretation and classification, the defining function of viewpoint aspect being the grammatical expression of the speaker's perspective. 
Sentence (6a) exemplifies the progressive perfect; (6b) illustrates the case of the progressive habitual; and the sentence in (6c) contains an ingressive phrase converted into a progressive complex predicate. Based on the data, it can be stated that the phenomena related to the scope of the different categories and the output features of the aspectually complex phrases can always be determined compositionally.

\subsection{The relation of the two levels and the compositionality of situation aspect}

The interaction of the two aspectual levels makes the aspectual system of languages more complex, therefore the study of this type of interactions has to be an important part of aspectology, while studies related to the aspectual type of certain languages and their aspectual phenomena provide relevant information for the better understanding of the nature of this interrelation in general. This section deals with compositionality; more specifically, with viewpoint aspect as a basic factor of compositionally marking situation aspect. ${ }^{11}$

As has already been mentioned, if there is a viewpoint aspect marker in the sentence, only the eventuality portion focused on by the viewpoint category is semantically visible, i.e., referentially accessible. This also entails that if a viewpoint category, for example, the progressive, focuses on a subinterval of the eventuality expressed by the input predicate, then in the case of predicates that refer to complex eventualities (i.e., eventualities with two subeventualities) the viewpoint category can only refer to a subeventuality of the original eventuality. A progressive predicate cannot refer to the whole eventuality expressed by the input verb (including its initial and/or final point), which means that in the case of telic predicates the scope of the progressive only covers the process portion of the complex eventuality, i.e., a progressive predicate can only refer to the process part of the event in question, and not to the whole event. This is why the expression progressive event is somewhat paradoxical:

${ }^{11}$ In this paper I do not aim to discuss problems related to similar functions of the arguments and adjuncts of the predicate; I strictly concentrate on so far neglected phenomena related to these functions of the viewpoint system. For more on the aspectual functions of arguments and adjuncts, see Binnick (1991); Dowty (1979; 1986); Michaelis (2002); Smith (1986; 1991); de Swart (2000); Tenny (1994); Verkuyl (1972; 2005), and others. 
progressive event predicates are in fact (progressive) processes, i.e., complex atelic predicates. The progressive counterparts of the telic predicates from sentences (7a) and (8a) are also atelic based on the relevant telicity tests, ${ }^{12}$ i.e., they are derived process predicates (see sentences $(7 \mathrm{~b}-\mathrm{c}$ ) and $(8 \mathrm{~b}-\mathrm{c}))$. Accordingly, it can be established that a detelicising conversion takes place in these cases: the progressive viewpoint changes the situation aspect of the telic input predicate, because the inherent final point becomes semantically invisible, and the only available part left is the process part. ${ }^{13}$

(7) (a) Tom ate the apple in ten minutes.

(b) Tom was eating the apple for ten minutes.

(c) ${ }^{*}$ Tom was eating the apple in ten minutes.

(8) (a) Péter 50 másodperc alatt lefutott a domboldalon.

Peter 50 second in down-ran the hill-superess

'Peter ran down the hill in 50 seconds.'

12 The practice of applying the known telicity tests to phrases that contain grammatical viewpoint markers may seem as a misuse of this test type, but-according to the definition of situation aspect adopted here (cf. Verkuyl 2005; Kiefer 2006) - aspectual features, like that of telicity, are compositionally encoded on the VP or even sentence level, therefore there is no reason why a telicity test should not apply to sentences with predicates already marked for viewpoint aspect.

13 This is also supported by the conclusions presented in Piñón (1995). According to his theory, the progressive forms of process expressions and event expressions are derived differently: in the case of progressive processes the derivation takes place directly, while in the case of telic input predicates a transitional conversion takes place before the progressive conversion, that of the transformation of event predicates into process predicates (cf. op.cit., 162). Though in a totally different framework and with different aims than the ones formulated in the present paper, this need for operating with a conversion of this type shows that, in the case of progressive predicates derived from telic input verbs, we are dealing with detelicised predicates. Bertinetto and Delfitto (2000) make a similar assumption, emphasising that the progressive and - generally - the imperfective detelicise the input predicate. According to the authors, the imperfective form il écrivait sa thèse of the telic predicate écrire sa thèse 'to write his/her thesis' loses its inherent [+Telic] feature, in opposition to the perfective form il a écrit sa these, i.e., the French imperfective also detelicises (cf. Bertinetto-Delfitto 2000, 191-3). This type of data are especially important regarding the discussion of problems related to the components of situation aspect and the perfective-imperfective opposition, in view of the fact that Smith (1991) considers the French aspectual system a prototypical example of the total independence of situation aspect and viewpoint aspect from one another. 
(b) Péter 50 másodpercen keresztül (csak)'futott'le a domboldalon. Peter 50 second-superess through just ran down the hill-superess 'Peter was running down the hill for 50 seconds.'

(c) *Péter 50 másodperc alatt'futott'le a domboldalon. Peter 50 second in ran down the hill-superess 'Peter was running down the hill in 50 seconds.'

In addition to the fact that the progressive, by definition, places the RT inside the ET, and consequently the focused part does not contain the starting and final points of the ET, there is also a way of linguistically capturing the difference regarding the (event-)structural scope of perfective vs. progressive viewpoint categories. In $(9 \mathrm{a}-\mathrm{d})$ below, we illustrate the phenomenon called the imperfective paradox in the literature which I consider to be an argument supporting the claim that progressive viewpoint aspect "hides" the inherent final point of telic input predicates. (For more on the imperfective paradox and the examples originally used to illustrate it, see Dowty 1979.)

(9) (a) Between 9.20 and 9.22, Tom was eating the apple, but he didn't eat it (he never finished it).

(b) \#Between 9.20 and 9.22, Tom was eating, but he didn't eat.

(c) Péter 50 másodpercen keresztül (csak) 'futott

Peter 50 second-superess through (just) ran

'le a domboldalon, de nem futott le.

down the hill-superess but not ran down.

'Peter was running down the hill for 50 seconds, but he didn't run down the hill.'

(d) ${ }^{\#}$ Péter 50 másodpercen keresztül futott a domboldalon,

Peter 50 second-superess through ran the hill-superess

de nem futott.

but not ran.

'Peter ran on the hill for 50 seconds, but he didn't run.'

The examples in (9) show that progressive predicates derived from telic verbs do not necessarily entail the occurrence of the eventuality expressed by their original telic input predicate (see examples (9a) and (9c)), while progressive predicates derived from atelic verbs always entail the occurrence of the eventuality expressed by their original atelic input predicate (see examples (9b) and (9d)) (cf. Dowty 1979, 133-8). This indicates that 
in the case of progressive predicates derived from telic verbs, the inherent final point, i.e., the subeventuality that makes these input predicates telic, is extracted from the original event structure, and in this way the process portion of the complex eventuality remains the only referentially accessible (sub)eventuality in the output event structure.

It can be observed that the other viewpoint categories can also have similar functions as the progressive does. The ingressive and the egressive aspects have the opposite, telicising function. The case of ingressive and egressive aspect expressed by aspectual verbs is illustrated by the sentences (4b) and (4d), or by the following Hungarian examples: elkezdett futni 'he/she began to run', befejezte a futást 'he/she stopped running', megszünt fájni '(it stopped hurting) $\approx$ the pain stopped' etc.), where the categories are not grammatically encoded, but they are in fact lexically expressed by telic aspectual verbs. In opposition to these cases, in languages like Russian, where these categories can be marked morphologically (e.g. govorit' 'to speak' - zagovorit' 'to start speaking'), aspect marking is a morphological operation, and its result is telicisation.

The use of prospective aspect illustrated in sentence (4a) results in atelic output predicates, i.e., process or stative predicates; the perfect and the resultative illustrated in $(4 \mathrm{e}-\mathrm{f})$ convert the input predicate into stative predicates according to the known linguistic tests and the subinterval criterion, i.e., telic input predicates are transformed into complex output predicates with the features [-Telic, -Dynamic]. Finally, mention must be made of the categories of quantificational aspect which also change the situation aspect of the input predicate. The (English) existential and habitual aspectual categories (see $(6 a, c)$ ) transform any type of situation aspect into stative situation aspect according to the test based on the subinterval property, while iterative aspect transforms event input predicates into process predicates (see $(6 \mathrm{~b})$ or the following Hungarian example: Elment, de aztán egy órán keresztül még fel-felnézett ' $\approx$ He left, but he kept looking up for half an hour').

According to the approach presented here, viewpoint aspect (in its traditional or in its modified interpretation) cannot be classified as a level independent of situation aspect, because it frequently changes the initial situation aspect assigned to the predicate/sentence. As opposed to situation aspect, it is not a universal component: there are languages, for example Finnish, which completely lack grammatical viewpoint aspect. Taking all these facts into consideration, it seems tenable that situation aspect is a basic component and that viewpoint aspect con- 
stitutes a secondary system which is part of the compositional model of aspectuality.

Grammatical viewpoint aspect is an important domain of aspectology in itself, but it is essential to clarify the questions related to viewpoint aspect as a factor that influences the situation aspect of predicates/sentences. The approach outlined here furnishes an adequate basis for studying these problems and, at the same time, it yields supplementary observations for modelling the level of situation aspect. Another advantage of such a framework is that it does not imply operating with the category of neutral viewpoint aspect introduced by Smith (1991), because it is based on the assumption that only the level of situation aspect is universally present in the aspectual system of languages.

My approach makes the question of the exact relation of the two levels - specifically, the relation between the level of the prefectiveimperfective opposition and that of telicity-atelicity-unavoidable. A conception like this raises the question whether there is any difference between the two levels, aside from the means of marking, i.e., if it is sustainable that perfective aspect presents the eventuality expressed by the predicate as an event, while the imperfective presents the same eventuality as a process. The lexical-compositional encoding of situation aspect and the grammatical expression of the perfective-imperfective opposition result in essential grammatical differences; nevertheless, the similar/different nature of the two levels is still a debated issue of aspectology.

Apart from Smith (1991), Borik (2002), Borik-Reinhart (2004), and Bertinetto-Delfitto (2000) also argue that the two levels are essentially different and independent, while Michaelis (2002) represents the opposite approach. ${ }^{14}$ The problem needs detailed analysis, which is not the subject matter of the present paper, as my aim here is to discuss the phenomena related to the interaction of the categories belonging to the two aspectual levels, and to verify my theoretical conclusions by applying them to the Hungarian aspectual system that lacks a grammatical perfectiveimperfective opposition. Nevertheless, my general observation is that an

14 The approaches outlined in É. Kiss (2005; 2006b) and Kiefer (2006) also imply the homogeneity of the two components. Besides the authors' arguments for the mutual deducibility of telicity and perfectivity, É. Kiss (2005) points out that there is a recurrent diachronic tendency in the history of languages to eliminate the grammatical marking of the perfective-imperfective viewpoint opposition during the grammaticalisation process of the telic-atelic opposition (ibid., 432-2). 
important function (or consequence) of using viewpoint categories is that of creating event-process minimal pairs (see (10b-c) below).

(10) (a) Tom ran.

(b) Tom ran into the building.

(c) Tom was running into the building when I saw him.

The sentences in $(10 \mathrm{a}-\mathrm{c})$ above illustrate a situation aspect opposition (that of $(10 \mathrm{a}-\mathrm{b})$ ) and a viewpoint opposition that is also a compositional situation aspect opposition at the same time (see $(10 \mathrm{~b}-\mathrm{c})$ ), the only difference in the semantics of the latter being the feature of telicity/atelicity - the rest of the aspectual and semantic features are identical. This type of opposition enriches the aspectual system of any language with viewpoint categories. Continuing this chain of thought, it is not surprising that studying languages that systematically encode the perfective-imperfective opposition at the level of aspectual morphology (e.g. Slavic languages) and the aspectual morphemes (or some of the aspectual morphemes) have lost their semantic content, the question whether the derivation of aspectual categories belongs to the level of viewpoint aspect or to that of situation aspect always arises. For the discussion of these languages the question related to the equivalence of the two levels is elementary, yet unsolved.

\subsection{Summary}

The first part of the paper was concerned with some theoretical questions related to aspectuality; more specifically, to the two levels of aspectuality: viewpoint aspect and situation aspect. I have also presented an outline of a general aspectual framework based on linguistic data and on the conclusions of the most influential aspect theories.

There are some phenomena and domains of aspectuality-e.g. the nature of aspectual compositionality and the role of viewpoint aspect in marking semantic aspectual categories - that cannot be adequately explained within the confines of previous modern theories. Based on the arguments presented, the two levels cannot be considered independent, because - as has been shown - viewpoint categories often change the situation aspect of the input predicate; therefore, the level of viewpoint 
aspect should also be discussed as a subsystem of compositional situation aspect. The approach presented above can have an important role in describing and modelling aspectuality.

\section{The Hungarian viewpoint categories}

This section serves as an application of the theoretical approach defined in the previous section to the Hungarian aspectual system. As we have seen, the modified two-component theory presented in section $\mathbf{I}$ interprets viewpoint aspect as a subsystem of categories compositionally encoding situation aspect - the other means of compositional marking being the argument structure and the adjuncts of the predicate. The present section aims at presenting some Hungarian viewpoint categories, emphasising the role they play in defining the situation aspect of the phrase/sentence.

Section 2.1 describes the Hungarian progressive which is defined as being a so-called preaspectual category in terms of Johanson (2000), ${ }^{15}$ and from the point of view of situation aspect it is presented as an aspectual operator that converts events into processes or does not change the situation aspect of a process predicate. Section $\mathbf{2 . 2}$ describes the Hungarian existential construction type which, in turn, is presented as an operator that changes any kind of input predicate into a complex event predicate. Section $\mathbf{2 . 3}$ describes two types of habitual constructions present in Hungarian (and in other languages as well, e.g. English) and regards habituality as an aspectual operator that results in complex process predicates when added to the structure of any type of input predicate. Finally, section $\mathbf{2 . 4}$ presents two resultative construction types: the eventive resultative which does not change the input situation aspect, and the stative resultative which is presented as an aspectual operator that converts any type of input predicate into complex stative predicates.

The other categories mentioned before (the ingressive and the egressive) are not presented separately: according to Kiefer $(2006 ; 2007)$, Gyuris-Kiefer (2008), and Maleczki (2001), the phenomenon related to

${ }^{15}$ Johanson describes the category as follows: "Since there are diachronic developments leading from peripheral constructions without aspectotemporally determining force to highly grammaticalized viewpoint operators, we may in many cases speak of preaspectual items. They do not reach the degree of generalization expected from aspectotenses. [...] The more limited the applicability of a preaspectual marker is, the longer its way is to the status of a viewpoint operator" (op.cit., 41). 
viewpoint categories marked by morphological Aktionsart belong to the range of lexical semantics. ${ }^{16}$ Neglecting morphological Aktionsart here is also supported by the fact that Kiefer (2006) presents these categories with special attention to the restrictions related to the input predicate and the aspectual features of the output predicates, thus the role of these categories in modifying the situation aspect expressed by the verb is deducible in each case.

Before presenting the categories, it is important to emphasise that the following subsections only aim to draw the outlines of the specific viewpoint categories - mostly preaspectual categories - existent in Hungarian, its main function being to set the bases of a more adequate, multi-dimensional aspectual model.

\subsection{The progressive}

The Hungarian literature on the topic generally defines as progressive predicates the ones similar to those in $(11 \mathrm{a}-\mathrm{d})$ below. The category is described as having the function of expressing that the process described by the predicate is in progress during the interval of the RT assigned to the sentence. The difference between the progressive and the simple continuous aspect is that the former has limited time reference which, in turn, has consequences in the distributional pattern of the predicate (cf. Kiefer 2006, 93-135).

(11) (a) Anna (éppen) a disszertációján dolgozott,

Anne just the thesis-poss.3sg-superess worked

amikor beléptem a szobába.

when in-stepped-1sg the room-illat

' $\approx$ Anne was working on her thesis when I entered the room'

(b) Anna éppen felolvasott Péternek, amikor...

Anne just up-read Peter-dat when

$" \approx$ Anne was reading to Peter when...'

(c) Anna éppen'olvasta'fel a levelet, amikor Péter megérkezett.

Anne just read up the letter-acc when Peter arrived

'Anne was reading the letter when Peter arrived.'

16 The fact that the morphological Aktionsart of the predicate cannot be modified by the syntactic position of the preverb also supports this observation. 
(d) A gyerekek éppen'festették 'zöldre a kerítést, amikor... the children just painted-3pl green-subl the fence-acc when 'The children were painting the fence green when...' (Kiefer 2006, 95-101)

(12) (a) Anna a disszertációján dolgozott.

Anne the thesis-poss.3sg-superess worked ' $\approx$ Anne was working on her thesis.'

(b) Éva a kertben sétált.

Eve the garden-iness walked

‘ Eve was walking in the garden.'

(ibid., 96)

(13) (a) Pista nagy munkában van.

Steve big work-iness is

' $\approx$ Steve is in the process of working hard.'

(b) A labda még mozgásban volt, amikor megláttam. the ball still motion-iness was when spotted-1sg ' $\approx$ The ball was still in the process of moving when I spotted it.'

The predicates in (11a-d) above are progressive according to Kiefer (1992a; 2006) and Piñón (1995). Kiefer (2006) points out that in the case of simple continuous predicates, the aspectual category of the predicate cannot be determined without the specification of the context. The examples in (12) can have either a progressive or a simple continuous interpretation depending on the presence or absence of a sentence or adverbial that specifies the RT assigned to the predicate. This shows that this approach operates with a progressive meaning in general, i.e., the classification is not limited to syntactically encoded (grammatical) progressivity (the category marked in Hungarian by word order and a specific intonation pattern). The present subsection concentrates on the syntactically encoded preaspectual category of the progressive, and it neglects data that show an optional progressive meaning, like the examples in (12), and also examples like those in (13) which obviously contain stative predicates but have a progressive meaning. Accordingly, in my view, the preaspectual viewpoint category of the progressive is always marked by the syntactic and intonational pattern mentioned and illustrated above. ${ }^{17}$

${ }^{17}$ On the problems related to the syntax of the progressive, see É. Kiss (1992; 2006c); Piñón (1995); Alberti (2001); Csirmaz (2006); for the semantic-pragmatic and information structure features of the category, see Maleczki (2001).

Acta Linguistica Hungarica 59, 2012 
The reason why I consider the Hungarian progressive a preaspectual category is that its productivity is limited: aside from the natural incompatibility with phrases without preverbs or other delimiting modifiers, the construction type has limited productivity in the range of verbal phrases containing preverbs/delimiting modifiers. The productivity restrictions which apply to the progressive construction type are related to the compositional meaning of the phrase and to the semantic transparency of the preverb (cf. Kiefer 2006, 93-102).

According to the arguments presented in section 1.2.2 above, progressive predicates are processes at the level of situation aspect; i.e., they have the features [-Telic, +Dynamic]. The adequate tests for verifying the feature of telicity are the ones illustrated below: the test based on adverbial modification is repeated in $(14 \mathrm{a}-\mathrm{c})$, while the examples in $(15 \mathrm{a}-$ d) illustrate an additional test type taken over from Kiefer (2006), the simultaneity test that can also be used to detect telicity. ${ }^{18}$

(14) (a) Péter 50 másodperc alatt lefutott a domboldalon.

Peter 50 second in down-ran the hill-superess

'Peter ran down the hill in 50 seconds.'

(b) Péter 50 másodpercen keresztül (csak)'futott'le

Peter 50 second-superess through just ran down

a domboldalon.

the hill-superess

'Peter was running down the hill for 50 seconds.'

(c) *Péter 50 másodperc alatt 'futott'le a domboldalon.

Peter 50 second in ran down the hill-superess

'Peter was running down the hill in 50 seconds.'

18 The tests, originally used to distinguish perfective predicates from imperfective ones, are based on the temporal reference features of the predicates in question. Sentence (15a) contains a coordinate clause that describes a process the ET of which overlaps with that of the predicate from the other sentence if it is atelic (imperfective), and it follows it if the predicate in question is telic (perfective). Sentence (15b) exemplifies the case of giving the RT of the tested predicate by means of a temporal adverbial subordinate clause with describing an instantaneous eventuality: the RT (and ET) of telic (perfective) predicates follow the ET of the instantaneous eventuality, i.e., there is no overlap, while the ET of atelic (imperfective) predicates always contains the ET of the instantaneous eventuality, i.e., there is an overlap of the two ETs. Finally, (15c) and (15d) are examples of the simultaneity tests based the use of the adverbials még 'still' and már 'already' and on verifying their influence on the relation of the ET and RT assigned 
(15) (a) Péter'futott'le a domboldalon, és ordított.

Peter ran down the hill-superess and yelled

' $\approx$ Peter was running down the hill and yelling.'

(b) Péter'futott'le a domboldalon, mikor a villám

Peter ran down the hill-superess when the lightning

belecsapott a fába.

struck the tree-illat

' $\approx$ Peter was running down the hill when the tree was struck by lightning.'

(c) 12-kor Péter még'futott'le a domboldalon.

12-at Peter still ran down the hill-superess

'At 12 o'clock Peter was still running down the hill.'

(d) Amikor megérkeztünk, Péter már 'futott'le a domboldalon.

when arrived-1pl Peter already ran down the hill-superess

'When we arrived Peter was already running down the hill'

Based on compatibility with durative temporal modifiers tested in sentences $(14 \mathrm{a}-\mathrm{c})$, the progressive predicate of sentence $(14 \mathrm{~b})$ is atelic, which is shown by the fact that - in opposition to the telic input predicate in (14a) - it does not combine with delimiting durative adverbials, while its combination with non-delimiting durative adverbials results in grammatical sentences. In addition, the construction type can also be labelled atelic based on the simultaneity tests illustrated by the examples in (15a-d): the two predicates in (15a) express simultaneity without any temporal modifier; the ET assigned to the progressive predicate from sentence (15b) contains the ET of the instantaneous predicate of the temporal adverbial clause; the combinations with the adverbs még and már illustrated in sentences $(15 \mathrm{c}-\mathrm{d})$ also show that the predicates in question are atelic.

The dynamicity of progressive predicates is undisputable, dinamicity being the main restriction on the input verb of progressive predicates, which is also shown by the fact that the most frequently used dynamicity test is based on the grammaticality of the progressive form or the combination with adverbials of progressive meaning (cf. Vendler 1967; Smith

to the predicate tested. The use of an RT-specifying temporal adverbial or subordinate clause combined with the adverbial még triggers a partial simultaneity interpretation in the case of atelic predicates, while in the case of telic predicates the same combination results in a successivity interpretation. The same holds for combinations with the adverb már, except that it triggers a precedence interpretation in the case of telic predicates. For more on these test types see Kiefer (2006, 34-40). 
1991; Kiefer 2006, etc.). Sentence (16) gives the dynamicity test based on compatibility with the adverb javában. ${ }^{19}$

(16) Péter javában'futott 'le a domboldalon,

Peter javában ran down the hill-superess

amikor belecsapott a villám a fába.

when struck the lightning the tree-illat

" $\approx$ Peter was in the process of running down the hill when the tree was struck by lightning.'

Taking examples (14)-(16) into consideration, it can clearly be established that progressive predicates are processes at the level of situation aspect, as they have the aspectual features [-Telic, +Dynamic] based on the relevant linguistic tests.

As far as the subinterval property test is concerned, the same conclusion can be drawn: if it is sustainable that someone was running down the hill betweeen $12: 10$ and 12:12, then the occurrence of the same eventuality of running down the hill is true for many subintervals of the original ET.

\subsection{Existential aspect}

Existential aspect belongs to the subcategory of quantificational aspect. In the case of phrases containing preverbs or other delimiting modifiers, it is marked by word order identical to that of the progressive (the verb precedes the preverb/delimiting modifier) and a different intonation pattern specific to the category (see exampless $(17 \mathrm{a}-\mathrm{c})$ ). In the case of phrases without preverbs or other delimiting components (i.e., process and stative predicates), existential aspect is only expressed by the intonation pattern mentioned (see $(18 \mathrm{a}-\mathrm{c}))$. This intonation pattern is similar to the prosody of focus: the verb is stressed and the succeeding components are always stressless.

(17) (a) 'Írtam (már) meg cikket éjjel.

wrote-1sg already prtmeg article-acc at.night

'I have written an article during the night before.'

19 The approximate meaning of the adverb is that the eventuality expressed by the predicate modified by it has already started and is (pretty much underway but) still in progress. Another similar dynamicity test is based on compatibility with the adverb egyre csak which is translated into English by the duplication of the verb, e.g. Egyre csak futottam... 'I ran and ran'. 
(b) 'Pattant (már) el az ablaküveg a hidegtől. cracked already prt $_{\mathrm{el}}$ the windowpane the cold-ablat 'The window has cracked because of the cold weather before.'

(c) 'Rúgtam (már) be alkoholmentes sörtől.

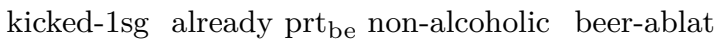
'I have got drunk on non-alcoholic beer before.'

(18) (a) 'Futottam (már) fapapucsban. ran-1sg already wood.slippers-iness 'I have run in clogs before.'

(b) 'Laktam (már) kollégiumban. lived-1sg already dormitory-iness 'I have lived in a boarding school before.'

(c) 'Voltam (már) lázas. was-1sg already feverish 'I have been feverish before.'

The examples in (17) and (18) above illustrate that existential predicates can be derived from predicates of each situation aspect category. Based on the above examples of existential predicates derived from preverb + verb constellations, it can be established that the productivity restrictions of the progressive do not hold for the existential: the compositional meaning of the phrase, the semantic transparency of the preverb and the durativity of the input predicate are not relevant input criteria. These observations are also supported by the fact that the fully lexicalised preverb + verb structures do not behave as one single lexical item in these cases $^{20}$ (see example (17c)), and by the grammaticality of sentences like (17b). Sentences (18a-c) also show the unlimited productivity of the construction type illustrating that it can also be produced from any type of atelic predicate (regardless to the feature $[ \pm$ Dynamic $]$ ).

The existential construction itself can be defined as a structure that states the occurrence of the eventuality expressed by the predicate. The component introduced into the semantics of the sentence can be formulated as follows: 'It has occured before that...' Accordingly, the semantic-aspectual structure of existential sentences is captured in (19) below.

${ }^{20}$ All preverbs, i.e., not only the semantically transparent ones, are separable from the verb. 
(19) It has occured before that $\operatorname{PRED}_{[ \pm \text {Telic, } \pm \text { Dynamic }]}$

The semantic component 'it has occured before' implies telicity, and thus - intuitively speaking - this suggests that the aspectual effect of using the existential is telicisation in the case of atelic input predicates. The literature on the topic also confirms this assumption in a way: Wacha (2001) classifies the construction type as a subcategory of the non-imperfective, ${ }^{21}$ while Kiefer (2006) points out that in the case of existential sentences the main emphasis is on existential quantification and not on the eventuality expressed by the input predicate, therefore these sentences are perfective even if they contain an imperfective predicate (cf. Wacha 2001, 80; Kiefer 2006, 71). The tests of adverbial modification are applied in (20) and (21) below.

(20) (a) 'Írtam meg cikket két nap alatt. wrote-1sg prtmeg article-acc two day in

'I have written an article in two days before.'

(b) 'Pattant el az ablaküveg két másodperc alatt. cracked $_{\text {prt }}$ el the windowpane two second in 'The window has cracked in two seconds before.'

(c) 'Rúgtam be alkoholmentes sörtől egy óra alatt.

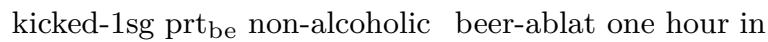
'I have got drunk on non-alcoholic beer in an hour before.'

(d) *'Futottam (már) fapapucsban két perc alatt. ran-1sg already wood.slippers-iness two minute in 'I have run in clogs in two minutes before.'

(e) *'Laktam (már) kollégiumban egy hónap alatt. lived-1sg already dormitory-iness one month in 'I have lived in a boarding school in a month before.'

(f) *'Voltam (már) lázas két hét alatt. was-1sg already feverish two week in 'I have been feverish in two weeks before.'

(21) (a) *'Írtam meg cikket két napon keresztül. wrote-1sg prtmeg article-acc two day-superess through 'I have written an article for two days before.'

${ }^{21}$ Based on the tests used to distinguish this category, it can be concluded that Wacha's term non-imperfective refers to "non-atelic" predicates, accordingly it would translate to the terminology applied here as telic. 
(b) *'Pattant el az ablaküveg két másodpercen keresztül. cracked prt $_{\text {el }}$ the windowpane two second-superess through 'The window has cracked for two seconds before.'

(c) *'Rúgtam be alkoholmentes sörtől egy órán keresztül. kicked-1sg prt be non-alcoholic beer-ablat one hour-superess through 'I have got drunk on non-alcoholic beer for an hour before.'

(d) 'Futottam (már) fapapucsban két percen keresztül. ran-1sg already wood.slippers-iness two minute-superess through 'I have run in clogs for two minutes before.'

(e) 'Laktam (már) kollégiumban egy hónapon keresztül. lived-1sg already dormitory-iness one month-superess through 'I have lived in a boarding school for a month before.'

(f) 'Voltam (már) lázas két héten keresztül. was-1sg already feverish two week-superess through 'I have been feverish for two weeks before.'

The examples show that existential constructions only allow temporal modifiers that are compatible with the situation aspect of their input predicate-but this does not mean that we can determine the situation aspect of existential predicates by means of this test. The phenomenon indicates that the highest-level predicate of the construction type, existential quantification, is not in the scope of these temporal adverbs. The temporal modifiers in the above sentences modify the predicate subordinate to existential quantification, and the resulting construction figures in the structure as a whole. Consequently, the linguistic test based on compatibility with temporal modifiers is not an adequate test for determining the situation aspect of existential predicates.

(22) (a) 'Mostam fel lépcsőt, és énekeltem.

washed-1sg up stairway-acc and sang-1sg

' I have been washing the stairs up and singing.'

(b) 'Mostam fel lépcsőt, amikor megérkeztek a vendégek. washed-1sg up stairway-acc when arrived-3pl the guests

' $\approx$ I have been washing the stairs up when the guests arrived.'

(c) *12-kor még'mostam (már) fel lépcsőt.

12-at still washed.1sg already up stairway-acc

'I have been still washing the stairs up at 12 o'clock before.' 
(d) 12-kor már 'mostam (*már) fel lépcsőt.

12-at already washed-1sg already up stairway-acc

'I have been washing the stairs up at 12 o'clock.'

Sentences (22a-d) do not constitute supplementary linguistic tests, either. In the case of $(22 a-b)$, the same pattern holds as of sentences $(20 a-f)$ and $(21 \mathrm{a}-\mathrm{f})$ : the coordinate clause in (22a) and the temporal adverbial clause in $(22 \mathrm{~b})$ contribute to the temporal reference specification of the sentence at the level of the input predicate that is subordinate to existential quantification, and not at the level of the whole predicative construction (sentence (22a) means that it has occurred before that I washed the stairs up singing; while the meaning of $(22 \mathrm{~b})$ is that it has happened before that I was washing the stairs up when the guests arrived). Finally, sentence (22c) is agrammatical because of the incompatibility of existentiality and the adverb még 'still', while (22d) can only be interpreted according to the semantic structure of (22b). This way it can be established that, as a natural consequence of the temporal reference structure of existential quantification, the situation aspect of existential predicates cannot be determined by means of the known linguistic tests.

Since it is impossible to assign delimiting adverbial modifiers to existential quantification itself, and consequently the feature of (a)telicity cannot be verified based on linguistic evidence, the only test that can be applied here is that of the subinterval property: if it is sustainable that during the time interval preceding the ST (e.g. sentence (23a)) or during a determined time interval in the past (e.g. sentence (23b)) it happened to someone that he/she ran in clogs or slept in the afternoon, then-due to the unspecified ET - the eventuality expressed by the existential predicate can only hold for the whole time interval (in our examples, the time interval of the past or that of the summer holiday). Based on this, existential sentences can be characterised by non-distributivity regardless of the distributivity or non-distributivity of the input predicates.

(23) (a) 'Futottam fapapucsban.

ran-1sg wood.slippers-iness

'I have run in clogs before.'

(b) A nyári vakációban 'aludtam délután.

the summer.adj holiday-iness slept-1sg in.the.afternoon

'During the summer holiday it occured that I slept in the afternoon.' 
According to the arguments presented in the literature and those presented above, it is sustainable that predicates of sentences expressing existential quantification are complex event predicates, i.e., they have the features [+Telic, +Dynamic], and that the use of existential viewpoint results in an event output irrespective of the situation aspect of the input predicate.

\subsection{Habituality}

Another category of quantificational aspect is habituality, which is also marked at a level higher than that of aspectual morphology. The semantic component introduced into the structure can be captured as follows: the eventuality expressed by the input predicate is/was regularly repeated as a routine during a time interval. The predicates in $(24 a-e)$ below are generally considered to be habitual.

(24) (a) Zoli drogozik/drogozott.

Zoli takes.drugs/took.drugs

'Zoli takes/took drogs.'

(b) Tamás sportol/sportolt.

Tom goes.in.for.sports/went.in.for.sports

'Tom does/did sports [ $\approx$ he is/was a sportsman].'

(c) Zoli szokott drogozni.

Zoli used.to take.drugs-inf

' $\approx$ Zoli takes drogs.'

(d) Péter meg szokta írni a leckéjét.

Peter prtmeg used.to write-inf the lesson-poss.3sg-acc

'Peter usually does his homework.'

(e) Mari télen náthás szokott lenni.

Mary winter.in having.a.cold used-to be-inf

'Mary usually has a cold in winter.'

As the examples illustrate, aside from the use of the adverbials like naponta 'daily', hetente 'weekly', gyakran 'frequently', rendszeresen 'regularly', etc., there are two ways of expressing habituality in Hungarian: by using the auxiliary verb szokott 'used to (present)' and by means of habitual coercion which is present in many languages. These two types of encoding habituality have partly different characteristics. 
According to Kiefer (2006), the habitual interpretation of sentences like $(24 a-b)$ - as opposed to their primary interpretation - is restricted by two criteria: the input predicate cannot be an event or a state (i.e., it has the features [-Telic, +Dynamic]) and the process (activity) expressed by the predicate has to be one that is not generally characteristic of any possible subject. The importance of the first criterion is illustrated by sentences $(26 \mathrm{a}-\mathrm{c})$ where the only possible interpretation is the actual one, while the relevance of the second restriction is shown by examples $(25 \mathrm{a}-$ c) where the same interpretation pattern works because the predicates express common processes characteristic of any possible subject.

(25) (a) Pisti eszik.

Steve eat

'Steve is eating.'

(b) Pisti alszik.

Steve sleep

'Steve is sleeping.'

(c) Anna áll.

Anne stand

'Anne is standing.'

(26) (a) Anna elénekli a dalt.

Anne prt $_{\mathrm{el}}$-sing the song-acc

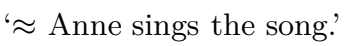

(b) Anna beteg.

Anne sick

'Anne is sick.'

(c) Péter fél Tamástól.

Peter fear Thomas-abl

'Peter is afraid of Tom.'

The restrictions presented do not hold in the case of constructions with the auxiliary szokott, which is shown by the grammaticality and habitual interpretation of the constructions in $(24 \mathrm{c}-\mathrm{e})$ derived from event, process and state predicates, respectively.

Smith (1991) considers habitual predicates to be derived states. The examples below serve as an application of the known linguistic tests of situation aspect. Sentences in (27) and (28) present the adverbial modification tests. 
(27) (a) *Zoli egy éjszaka alatt drogozott.

Zoli one night in took.drugs

'Zoli took drugs in a night.'

(b) Zoli egész éjjel/ egy éjszakán át drogozott. Zoli whole night one night-superess through took.drugs 'Zoli took drugs all night long/for a night.'

(c) Zoli öt éven át drogozott.

Zoli five year-superess through took.drugs

'Zoli took drugs for five years.'

(28) (a) *Zoli egy éjszaka alatt szokott drogozni.

Zoli one night in used.to take.drugs-ni

'Zoli usually takes drugs in a night.'

(b) Zoli két órán át szokott drogozni.

Zoli two hour-superess through used.to take.drugs-inf

'Zoli usually takes drugs for a night.'

(c) Péter egy óra alatt meg szokta írni a leckéjét.

Peter one hour in prtmeg used.to write-inf the lesson-poss.3sg-acc

'Peter usually writes his homework in an hour.'

(d) *Péter egy órán keresztül meg szokta írni a leckéjét.

Peter one hour-super. through prtmeg used.to write-inf the lesson-poss.3sg-acc

'Peter usually finishes writing his homework for an hour.'

From the point of view of compatibility, both types of habitual quantification have the same distributional pattern as existential quantification does: these contruction types only allow temporal modifiers that are compatible with their input predicates, because they modify the subordinate predicate and not the main predication. It is also important that the time interval expressed by the modifier has to be extended enough to trigger a habitual interpretation, i.e., it has to (semantically and pragmatically) fit the scale of habituality (e.g. sentence $(27 \mathrm{c})$ ), otherwise the modifier favours the actual meaning (e.g. sentence (27b)).

The simultaneity tests of telicity are given in $(29 \mathrm{a}-\mathrm{d})$ below for the cases of habitual coercion, while the tests cannot be applied in the case of the constructions with the auxiliary szokott. ${ }^{22}$

22 The szokott + inf construction type-similarly to its English counterpart, the used to + inf construction - can only be used referring to a determined temporal dimension: the Hungarian construction refers to the extended present, while its 
(29) (a) Ittam és dohányoztam.

drank-1sg and smoked-1sg

'I used to drink and smoke.'

(b) Ivott, amikor megismerkedett a feleségével. drank when got.acquainted.with the wife-poss.3sg.comit ' He used to drink when he got to know his wife.'

(c) Másfél éve még ivott. one.and.a.half year-poss.3sg still drank ' One and a half years ago he was still an alcoholic.'

(d) Másfél éve már ivott. one.and.a.half year-poss.3sg already drank ' $\approx$ One and a half years ago he was already an alcoholic.'

The coordinate clauses in sentence (29a) express two simultaneous eventualities that also allow for a habitual interpretation on the condition that both clauses have the same - actual or habitual -interpretation.

The restriction mentioned does not hold for sentences like (29b): the temporal interval assigned to the habitual predicate of the main clause contains the instantaneous predicate from the subordinate temporal adverbial clause; accordingly, the habitual predicate can be characterised by the feature [-Telic]. The tests based on combination with the adverbs még and már indicate the same pattern: the sentences in $(29 \mathrm{c}-\mathrm{d})$ refer to eventualities that started before the time point denoted by the adverbs. Based on all these, it is sustainable that in this case of aspectual quantification the feature $[ \pm$ Telic] can be verified by means of linguistic tests. The examples in $(30 \mathrm{a}-\mathrm{c})$ below are used to verify the feature $[ \pm$ Dynamic] of habitual constructions.

(30) (a) (Már) javában ittam/ drogoztam/ sportoltam, already javában drank-1sg took.drogs-1sg went.in.for.sports-1sg amikor megismertem öt.

when got.acquainted.with-1sg him/her

' $\approx$ I was an alcoholic/a drug-user/a sportsman when I got to know him/her.'

English counterpart only allows for a past tense interpretation. The possibility of extending these intervals is given by means of insertion of a coordinate clause (e.g. Zoli szokott drogozni, és már öt éve is drogozott ' $\approx$ Zoli is a drug-user, and he was five years ago, too'; or Comrie's $(1976,29)$ example: Bill used to belong to a subversive organisation, and he still does). 
(b) Egyre csak sportoltam, de nem javult az állóképességem. incessantly went.in.for.sports-1sg but not got.better the endurance-poss.1sg ' $\approx$ I used to do sports persistently but my fitness didn't get better.'

(c) Három éve elkezdtem inni/ drogozni/ sportolni. three year-poss.3sg started-1sg drink-inf take.drogs-inf get.in.for.sports-inf 'Three years ago I started drinking/taking drugs/doing sports.'

The examples in $(30 \mathrm{a}-\mathrm{c})$ show that combinations with the aspectual verb elkezd 'begin/start' and the adverbs javában and egyre csak can have a habitual interpretation. Accordingly, habitual viewpoint aspect results in complex process predicates. ${ }^{23}$

\subsection{The Hungarian predicative participle constructions: the stative and the eventive resultative}

The linguistic data and the observations presented in the literature on the topic lead to the conclusion that the main function of predicative participle constructions is expressing resultativity, which is semantically related to the perfect aspect (e.g. the English perfect); accordingly, the construction type can be considered a partial equivalent or substitute for the perfect enriching the Hungarian tense-aspect system. Based on the specific formation patterns and the semantic/pragmatic features of the construction type I argue that it is a perfect-like construction ${ }^{24}$ which belongs to the category of preaspectual items.

The common semantic-aspectual feature of the two subtypes of predicative participle constructions is that of resultativity, and the most important difference is that the stative resultative (VAN + verb- $v A$ ) constitutes one of the most productive structures of derived states in Hungarian, while the eventive resultative (LETT + verb- $v A$ ) belongs to the category of compositionally encoded events.

(31) (a) A kapu le van festve.

the gate prt $_{l e}$ is painted

'The gate is painted.'

${ }^{23}$ Kiefer (2006) also argues against the stativity of habitual predicates based on Dowty's tests of compatibility with imperative and with aspectual verbs (cf. op.cit., 78).

${ }^{24}$ In the literature the term perfect-like refers to the "relatives" of the perfect, mainly resultative constructions. 
(b) A beteg le van gyengülve.

the sick prt $_{l e}$ is weakened

'The patient is pulled down (by disease).'

(c) ?A fönököm el van utazva.

the boss-poss.1sg prtel is travelled

'My boss has departed.'

(d) *A könyv olvasva van.

the book read is

'The book is being read.'

(e) *A sportoló futva van.

the sportsman ran is

'The sportsman is run.'

(f) *Edit el van úszva.

Edith prt $_{\mathrm{el}}$ is swum

'Edith is swum away.'

(32) (a) A kapu le lett festve.

the gate prt $_{\mathrm{le}}$ became painted

'The gate has been painted.'

(b) $*$ A beteg le lett gyengülve. the sick prt $_{\text {le }}$ became weakened

'The patient has been pulled down.'

(c) *A főnököm el lett utazva.

the boss-poss.1sg prtel became travelled

'My boss has been departed.'

(d) *A könyv olvasva lett.

the book read became

'The book has been read.'

(e) *A sportoló futva lett.

the sportsman ran became

'The sportsman has been run.'

(f) *Edit el lett úszva.

Edith prt $_{\text {el }}$ became swum

'Edith has been swum away.'

Besides the well-formed examples in (31) and (32) above, there are some agrammatical examples that show the limited productivity of the construction types and the most important input restrictions. In the case of 
the stative resultative, the relevant input criteria are the telicity and the transitivity or unaccusativity of the base predicate, while in the case of its eventive counterpart the input criteria are the telicity and transitivity of the base predicate. ${ }^{25}$

The stativity of the VAN + verb-vA construction type is illustrated by applying the tests of dynamicity in $(33 \mathrm{a}-\mathrm{c})$ below.

(33) (a) *A kapu javában le volt festve, amikor eleredt az eső. the gate javában prt $_{\text {le }}$ was painted when started the rain ' $\approx$ The gate was being painted when it started to rain.'

(b) *Péter elkezdett le lenni gyengülve/ legyengülve lenni. Peter started prt $_{l e}$ be-inf weakened prt $_{l e}$-weakened be-inf 'Peter started being pulled down.'

(c) *Mari egyre csak el volt pirulva. Mary incessantly prt $\mathrm{el}_{\mathrm{l}}$ was flushed 'Mary was being flushed.'

Unlike the VAN + verb- $v A$ construction, the LETT + verb- $v A$ construction type results in complex event predicates according to the linguistic tests and the subinterval property (see sentences $(34 \mathrm{a}-\mathrm{b})$ below).

(34) (a) A kapu két óra alatt le lett festve.

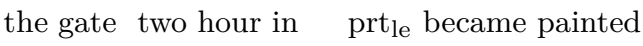

'The gate was painted in two hours.'

(b) *A kapu két órán át le lett festve. the gate two hour-superess through prt le became painted "The gate was painted for two hours.'

Based on the observations presented, from the perspective of situation aspect the stative resultative can be represented as a detelicising aspectual operator, see $(35 \mathrm{a})$, while the eventive resultative is a viewpoint operator that does not change the situation aspect of the input predicate, see (35b).

(35) (a) Stative resultative: $\operatorname{PRED}_{[+ \text {Telic; }}+$ Dynamic] $\rightarrow \operatorname{PRED}^{\prime}[\mathrm{RES}][-$ Telic; - Dynamic $]$

(b) Eventive resultative: $\operatorname{PRED}[+$ Telic; + Dynamic $] \rightarrow$ PRED $^{\prime}[$ RES $]$ [+Telic; +Dynamic $]$

${ }^{25}$ For more on the productivity restrictions of the two construction types, see Kádár-Németh (2010).

Acta Linguistica Hungarica 59, 2012 


\section{Summary}

The article puts forward an asymmetric two-component model of aspectuality, which it applies to the Hungarian aspectual system. The most important conclusions presented and verified in the paper are the following:

(i) The categorisation presented in Smith (1991), according to which the two elementary components of aspectuality are situation aspect and viewpoint aspect, is acceptable on the stipulation that there is a hierarchical relation between the two components.

(ii) The basic universal component is that of situation aspect (cf. Dahl 1985; Kiefer 1996). Viewpoint aspect is an (optional) additional component which is language specific (i.e., it is not a universal phenomenon), and it has an important role in the compositional encoding of situation aspect. Therefore the two components are not independent systems.

(iii) Situation aspect is a compositionally encoded category which is defined by the aspectual features assigned to the event structure of a predicate. The main aspectual features are $[ \pm$ Telic $]$ and $[ \pm$ Dynamic $]$, and their valid combinations result in the three basic categories of situation aspect: events [+Telic, +Dynamic], processes [-Telic, +Dynamic] and states [-Telic, -Dynamic] (cf. Dowty 1986; Smith 1991; Boland 2006 etc.).

(iv) Viewpoint aspect is a different component of the complex aspectual system. The categories that belong to this level are usually marked by grammatical means and are not inherent in the semantics of the predicate. Their function is focusing on a specific part or on the quantificational features of the event structure assigned to a predicate. As Smith (1991) and Boland (2006) point out, only the focused part(s) are available for the semantic interpretation. The categories labelled as viewpoint categories are the perfective, the imperfective, the ingressive, the progressive, the egressive and the perfect, and they are formally defined by the means of the well-known Reichenbachian tense system (speech time, event time and reference time).

(v) The viewpoint categories present in the Hungarian aspectual system are the following: the progressive, the existential, the habitual, the stative resultative and the eventive resultative. The progressive and the habitual result in complex process predicates, i.e., these categories have a detelicising function; the stative resultative construction results in complex stative predicates, i.e., the category changes the [+Telic, +Dynamic] 
feature values of the input predicate to [-Telic, -Dynamic]; finally, the existential and the eventive resultative result in complex event predicates (the former has a telicising function, while the latter leaves the input situation aspect unchanged due to the telicity requirement that holds for the input predicate of the construction type).

\section{References}

Alberti, Gábor 2001. Az aspektus szintaxisa a magyarban [The syntax of aspect in Hungarian]. In: Bakró-Nagy et al. (2001, 145-64).

Bakró-Nagy, Marianne-Zoltán Bánréti-Katalin É. Kiss (eds) 2001. Újabb tanulmányok a strukturális magyar nyelvtan és nyelvtörténet köréből. Kiefer Ferenc tiszteletére barátai és tanítványai [Papers on Hungarian grammar and the history of Hungarian. A Festschrift for Ferenc Kiefer]. Osiris Kiadó, Budapest.

Bertinetto, Pier Marco-Denis Delfitto 2000. Aspect vs. actionality: Why they should be kept apart. In: Dahl (2000, 189-225).

Binnick, Robert I. 1991. Time and the verb. A guide to tense and aspect. Oxford University Press, Oxford.

Boland, Annerieke 2006. Tense, aspect and quantification. In: Annerieke Boland (ed.): Aspect, tense and modality: Theory, typology, acquisition. Volume I, 35-66. LOT, Utrecht.

Borik, Olga 2002. Aspect and reference time (LOT Dissertation Series 64). Landelijke Onderzoekschool Taalwetenschap, Utrecht.

Borik, Olga-Tanya Reinhart 2004. Telicity and perfectivity: Two independent systems. In: Proceedings of the Eighth Symposium on Logic and Language. http://seneca.uab.es/clt/membres/postdoctorands/Borik/borik-reinhart-lola8.pdf (accessed: 09.10.2011)

Comrie, Bernard 1976. Aspect. Cambridge University Press, Cambridge.

Csirmaz, Anikó 2006. Particles and a two component theory of aspect. In: É. Kiss (2006a, 107-28).

Dahl, Östen 1985. Tense and aspect systems. Blackwell, Cambridge MA \& Oxford.

Dahl, Östen (ed.) 2000. Tense and aspect in the languages of Europe. Berlin, Mouton de Gruyter.

Dowty, David R. 1979. Word meaning and Montague grammar: The semantics of verbs and times in generative syntax and in Montague's PTQ. Reidel, Dordrecht.

Dowty, David R. 1986. The effects of aspectual class on the temporal structure of discourse: semantics or pragmatics? In: Linguistics and Philosophy 9:37-61.

É. Kiss, Katalin 1992. Az egyszerü mondat szerkezete [The structure of clauses]. In: Kiefer (1992b, 79-176).

É. Kiss, Katalin 2005. Az ómagyar igeidőrendszer morfoszintaxisáról [On the morphosyntax of the Old Hungarian tense system]. In: Magyar Nyelv 101:420-35. 
É. Kiss, Katalin (ed.) 2006a. Event structure and the left periphery. Studies on Hungarian. Springer, Dordrecht.

É. Kiss, Katalin 2006b. From the grammaticalization of viewpoint aspect to the grammaticalization of situation aspect. In: É. Kiss (2006a, 129-58).

É. Kiss, Katalin 2006c. The function and the syntax of the verbal particle. In: É. Kiss (2006a, 16-55).

Gyuris, Beáta-Ferenc Kiefer 2008. Az igék lexikai ábrázolása és az eseményszerkezet [The lexical representation of verbs and event structure]. In: Ferenc Kiefer (ed.): Strukturális magyar nyelvtan 4. A szótár szerkezete [A structural grammar of Hungarian 4. The structure of the lexicon], 229-67. Akadémiai Kiadó, Budapest.

Johanson, Lars 2000. Viewpoint operators in European languages. In: Dahl 2000, 27-187.

Kádár, Edit - Boglárka Németh 2010. The role of the predicative participle construction in the Csángó tense-aspect system. In: Philobiblon 15 : 194-225.

Kiefer, Ferenc 1992a. Az aspektus és a mondat szerkezete [Aspect and syntactic structure]. In: Kiefer (1992b, 797-886).

Kiefer, Ferenc (ed.) 1992b. Strukturális magyar nyelvtan 1. Mondattan [A structural grammar of Hungarian 1. Syntax]. Akadémiai Kiadó, Budapest.

Kiefer, Ferenc 1996. Az igeaspektus areális-tipológiai szempontból. In: Magyar Nyelv $92: 257-68$.

Kiefer, Ferenc 2006. Aspektus és akcióminőség. Különös tekintettel a magyar nyelvre [Aspect and Aktionsart - with a special emphasis on Hungarian]. Akadémiai Kiadó, Budapest.

Kiefer, Ferenc 2007. Aspektus, akcióminőség, eseményszerkezet [Aspect, Aktionsart, event structure]. In: Ferenc Kiefer (ed.): Jelentéselmélet [Semantic theory] (Second edition), 271-99. Corvina, Budapest.

Klein, Wolfgang 1994. Time in language. Routledge, London \& New York.

Maleczki, Márta 2001. Az információs szerkezet, a szintaktikai szerkezet és az aspektus összefüggései a magyarban: a progresszív és az egzisztenciális aspektus [The interrelation of information structure, syntactic structure, and aspect in Hungarian: The progressive and the existential aspect]. In: Bakró-Nagy et al. (2001, 165-81).

Michaelis, Laura A. 2002. Aspectual grammar and past-time reference. Routledge, New York.

Németh, Boglárka 2010. Aspektuselméletek összehasonlító vizsgálata. Egy általános aspektológiai keret kidolgozásának kérdései [A comparative study of theories of aspect. Issues in the development of a general framework for aspectology]. In: Nyelv- és Irodalomtudományi Közlemények 54:37-87.

Piñón, Christopher 1995. Around the progressive in Hungarian. In: István Kenesei (ed.): Approaches to Hungarian 5: Levels and structures, 153-90. JATEPress, Szeged.

Reichenbach, Hans 1947. Elements of symbolic logic. Collier-Macmillan, London.

Smith, Carlota 1986. A speaker-based approach to aspect. In: Linguistics and Philosophy $9: 97-115$.

Smith, Carlota 1991. The parameter of aspect. Kluwer, Dordrecht. 
Stutterheim, Christiane von-Mary Carroll-Wolfgang Klein 2009. New perspectives in analyzing aspectual distinctions across languages. In: Wolfgang Klein - Ping Li (eds): The expression of time, 195-216. Mouton de Gruyter, Berlin \& New York.

Swart, Henriette de 2000. Tense, aspect and coercion in a cross-linguistic perspective. In: Miriam Butt - Tracy Holloway King (eds): Proceedings of the Berkeley Formal Grammar Conference.

http://csli-publications.stanford.edu/LFG/5/bfg00/bfg00deswart.pdf (accessed: 09.10.2011)

Tenny, Carol L. 1994. Aspectual roles and the syntax-semantics interface. (Studies in Linguistics and Philosophy 52). Kluwer, Dordrecht.

Verkuyl, Henk J. 1972. On the compositional nature of the aspects. Reidel, Dordrecht.

Verkuyl, Henk J. 2005. Aspectual composition: Surveying the ingredients. In: Henk J. Verkuyl-Henriette de Swart-Angeliek van Hout (eds): Perspectives on aspect, 19-39. Springer, Dordrecht.

Wacha, Balázs 2001. Időbeliség és aspektualitás a magyarban [Temporality and aspectuality in Hungarian] (Nyelvtudományi Értekezések 149). Akadémiai Kiadó, Budapest. 